\title{
LWOWSKA KONGREGACJA KUPIECKA W OKRESIE MIĘDZYWOJENNYM ${ }^{1}$
}

\author{
Konrad Meus (D) http://orcid.org/0000-0002-6865-2174 \\ Uniwersytet Pedagogiczny w Krakowie
}

\section{ABSTRACT \\ LVIV MERCHANT CONGREGATION IN THE INTERWAR PERIOD}

In the interwar period, Lviv Merchant Congregation was undoubtedly one of the main organizations of the economic life in Eastern Lesser Poland. The importance of this organisation was visible in the increasing number of its members, who actually could count on the Congregation's support in the difficult times of economic depression. Although Lviv Merchant Congregation did not last long, in comparison to its long-lasting Cracovian counterpart, it noted many significant successes. The most important was the establishment of the Trade School in Lviv, which would function for many years. Another success was the promotion of products offered by merchants from the Congregation. Last but not least, there was a cooperation between the Lviv Merchant Congregation and Trade and Industry Chamber (both of which consisted of the same members) which aimed at improving commerce in Lviv during the interwar period.

Keywords: trade, Trade and Industry Chamber in Lviv, Lviv Merchant Congregation, commerce, Lviv, interwar period.

Słowa kluczowe: handel, Izba Przemysłowo-Handlowa we Lwowie, Kongregacja Kupiecka we Lwowie, kupiectwo, Lwów, międzywojnie.

${ }^{1}$ Handel lwowski (a szerzej w Galicji i później w Małopolsce Wschodniej) stanowi problem niezwykle złożony ze względu na specyfikę miasta i regionu, który pozostawał obszarem silnie wielonarodowym. Było to miejsce na mapie międzywojennej Polski, gdzie przeplatały się interesy licznych grup narodowych, od Żydów, Polaków i Ukraińców począwszy, a na Ormianach skończywszy. Tematyka ta pozostawała dotychczas dość słabo zbadana. Niniejszy artykuł ma na celu w niewielkim stopniu uzupełnić powstałą lukę. Tekst ten stanowi kontynuację tematu, który zapoczątkował Andrij Bezsmertnyi na łamach „Dziejów Najnowszych” oraz „Roczników Dziejów Społecznych i Gospodarczych”. A. Bezsmertnyj, Handel lwowski w okresie międzywojennym, „Dzieje Najnowsze”, R. XLVII, 2015, z. 2, Warszawa, s. 3-20; idem, Lwowskie organizacje kupieckie w okresie międzywojennym, „Roczniki Dziejów Społecznych i Gospodarczych” 2017, t. LXXVIII, s. 367-385 (DOI: http://dx.doi.org/10.12775/RDSG.2017.14)

Adres do korespondencji: konrad.meus@up.krakow.pl 
Pierwsze zinstytucjonalizowane stowarzyszenie skupiające kupców we Lwowie sięga czasów średniowiecznych. W 1408 roku wojewoda mołdawski Aleksander nadał pierwsze przywileje handlowe lwowskiego Bractwa (Fraternitas) trudniącego się kupiectwem. Organizacja piętnastowiecznej instytucji stała na wysokim poziomie, o czym między innymi świadczyło uzyskane w 1444 roku przez lwowian „prawa składu"2. W 1480 roku ze struktur wspomnianego Bractwa wyłoniona została Komisja Dobrego Porządku, która jako pierwsza otrzymała z rąk króla Zygmunta I Starego własny statut. Został on potwierdzony w XVII wieku przez Władysława IV. Niestety trudna sytuacja, w jakiej znalazła się ówczesna Rzeczpospolita, a w szczególności ciągnące się latami wojny, przyczyniły się do załamania lwowskiego handlu ${ }^{3}$ Jego pobudzenie nastąpiło w latach 70. XVII stulecia, tuż po zakończonej wojnie z Turcją. Tego okresu sięgają również właściwe tradycje Konfraternii Młodzieży Handlowej (Bractwo Młodzi Kupieckiej we Lwowie), poprzedniczki miejscowej (Lwowskiej) Kongregacji Kupieckiej (LKK). Jak wynika z informacji zawartych w nowszych archiwaliach Kongregacji oraz w odnalezionym w zbiorach Austriackiej Biblioteki Narodowej Statucie Młodzieży Handlowej we Lwowie, utworzono ją w 1673 roku4 Dwa lata później posiadała już własny statut. August II w 1714 roku nadał mu moc prawną . Patronką instytucji w 1683 roku wybrano Niepokalanie Poczętą Najświętszą Maryję Pannę. Jej święto przypadało każdego roku 8 grudnia. Dzień ten aż do wybuchu II wojny światowej był uroczyście obchodzony przez chrześcijańskich kupców skupionych wokół lwowskiej Kongregacji. Potwierdzeniem łączności tradycji historycznych Kongregacji z okresu międzywojennego do instytucji działających w czasach staropolskich miała być - w domyśle autorów projektu - uchwała LKK z 1934 roku, która wzorem statutu z 1675 roku umieszczała w godle organizacji wizerunek Niepokalanie Poczętej Najświętszej Maryi Panny7. 8 grudnia 1937 roku arcybiskup Lwowa Bolesław Twardowski dokonał aktu poświęcenia wspomnianego godła $^{8}$. Kontynuując rozważania na temat protoplastów LKK, należy wskazać, że już w 1771 roku Bractwo Młodzi Kupieckiej we Lwowie utworzyło samodzielną korporację?. Niestety ze względu na braki źródłowe trudno jednoznacznie wskazać, jak kształtowały się jej losy w latach kolejnych. Wiadomo natomiast, że w 1866 roku

${ }^{2}$ Centralne Państwowe Archiwum Historyczne Ukrainy we Lwowie / Центральний Державний Історичний Архів України у Львові (dalej: CDIAL), fond (dalej: f.) 702: Kongregacja Kupiecka we Lwowie, opis (dalej: op.) 1, sprawa (dalej: spr.) 30, k. 6.

${ }^{3}$ CDIAL, f. 702, op. 1, spr. 30, k. 6.

${ }^{4}$ CDIAL, f. 702, op. 1, spr. 30, k. 6; Statut Stowarzyszenia Młodzieży Handlowej we Lwowie, Lwów 1868, s. 3. Statut znajduje się w zbiorach Austriackiej Biblioteki Narodowej w Wiedniu / Österreichische Nationalbibliothek, sygn. 123111-B. Zob. także Skorowidz Przemystowo-Handlowy Królestwa Galicyi, wyd. 2, Lwów 1912, s. 182-183.

${ }^{5}$ CDIAL, f. 702, op. 1, spr. 30, k. 6; Statut Stowarzyszenia Młodzieży..., s. 3.

${ }^{6}$ CDIAL, f. 702, op. 1, spr. 29, k. 16; CDIAL, f. 702, op. 1, spr. 30, k. 6.

${ }^{7}$ Międzywojenne godło Kongregacji przedstawiał wizerunek NMP Niepokalanie Poczętej będący wizerunkiem rzeźby maryjnej znajdującej się w narożniku domu przy ówczesnej ulicy Czarneckiego i placu Bernardyńskim. A. Biedrzy cka, Kalendarium Lwowa 1918-1939, Kraków 2012, s. 884.

${ }^{8}$ CDIAL, f. 702, op. 1, spr. 30, k. 6.

${ }_{9}$ Statut Stowarzyszenia Młodzieży..., s. 3. 
Bractwo uzyskało nowy statut, a organizacja zaczęła nosić nazwę „Stowarzyszenie Młodzieży Handlowej we Lwowie” (rozszerzona nazwa brzmiała „Stowarzyszenie Wzajemnej Pomocy Kupców i Młodzieży Handlowej we Lwowie”) ${ }^{10}$. W tym miejscu warto też nadmienić, że zaledwie kilka lat po lwowskim Stowarzyszeniu Kupców i Młodzieży Handlowej, bo w maju 1876 roku, swoją działalność we Lwowie zainaugurowało Towarzystwo Lemberger Geschäftshalle (Towarzystwo Izby Kupieckiej), które należałoby potraktować jako instytucję bezpośrednio odwołującą się do historii średniowiecznego bractwa kupieckiego ${ }^{11}$. W latach 30. XX wieku władze LKK często nawiązywały właśnie do tradycji dziewiętnastowiecznej Izby Kupieckiej.

Oficjalnie Lwowska Kongregacja Kupiecka została uformowana w 1910 roku $^{12}$. Wydaje się, że ostateczny bodziec do jej założenia dał hucznie obchodzony wówczas w Krakowie jubileusz 500-lecia działalności Krakowskiej Kongregacji Kupieckiej, w którym uczestniczyli także kupcy lwowscy ${ }^{13}$. W rzeczywistości jednak środowisko rzymskokatolickich kupców ze Lwowa nosiło się z zamiarem utworzenia własnej organizacji od dłuższego czasu, co było spowodowane rosnącą w siłę od kilku lat konkurencją żydowską. Czołowym reprezentantem polskiego kupiectwa chrześcijańskiego we Lwowie był prezes Stowarzyszenia Kupców i Młodzieży Handlowej Walenty Halski ${ }^{14}$. Choć LKK posiadała odrębny statut, to jednak nowa organizacja była ściśle związana ze wspomnianym wcześniej Stowarzyszeniem Wzajemnym Pomocy Kupców i Młodzieży Handlowej we Lwowie. To drugie dokonało nawet zmiany własnego statutu, aby podkreślić związki z nowo powstałą Kongregacją ${ }^{15}$. Jedną z najważniejszych zmian dokonaną przez władze „stowarzyszenia młodzieżowego” było wprowadzenie zapisu mówiącego: „Członkowie, którzy wykonują samoistnie lub jako wspólnicy, dzierżawcy, względnie jako zastępcy przemysł handlowy stają się zarazem członkami Kongregacji Kupieckiej w razie wprowadzenia jej w życie i mają prawa i obowiązki statutem tejże Kongregacji nakreślone" ${ }^{16}$. W dalszych zapisach przewidywano nawet możliwość przekazania własnego majątku na rzecz LKK, co tylko udowadnia, że towarzystwo „młodzieży handlowej” we Lwowie odtąd miało odgrywać rolę quasi-młodzieżowej przybudówki Kongregacji ${ }^{17}$. W okresie międzywojennym oba stowarzyszenia nadal z sobą współpracowały ${ }^{18}$. Nierzadko relacje

10 Ibidem.

11 Państwowe Archiwum Lwowskiego Obwodu / Державний Архів Львівської Області / Derżawnyj Archiw Lwiwśkoji Obłasti (dalej: DALO), f. 1, op. 54, spr. 2178, k. 1-4.

12 DALO, f. 1, op. 54, spr. 2115, s. 122.

13 E. Wygonik-Barzyk, Krakowska Kongregacja Kupiecka. 600 lat istnienia, Kraków 2009, s. $145-147$.

14 „Kupiec Polski. Organ kupiectwa polskiego”, R. IV, nr 14, 15 VII 1910, s. 4-5.

15 DALO, f. 1, op. 54, spr. 2115, s. 122.

16 Ibidem.

17 Ibidem, s. 123.

18 Stowarzyszenie Wzajemnej Pomocy Kupców i Młodzieży Handlowej w 1934 r. decyzją Walnego Zgromadzenia postawiono w stan likwidacji. Decyzja ta stała się faktem w III 1938 r., kiedy swoją działalność zakończyła Komisja Likwidacyjna Stowarzyszenia. Majątek organizacji został m.in. przekazany do dyspozycji Wydziału Lwowskiej Kongregacji Kupieckiej z przeznaczeniem na cele charytatywne. DALO, f. 1, op. 54, spr. 2115, s. 219, 222, 224, 227. 
te były bardzo silne i wynikały z faktu przynależności do ich struktur tych samych osób. Każdorazowo prezes LKK piastował również stanowisko dyrektora Stowarzyszenia Kupców i Młodzieży Handlowej, z kolei wicedyrektor otrzymywał z urzędu funkcję I wiceprezesa Kongregacji ${ }^{19}$.

Ze względu na niedobór archiwaliów trudno wskazać, jak potoczyły się losy wspomnianych wcześniej lwowskich organizacji kupieckich w czasie okupacji rosyjskiej i I wojny światowej w ogóle. Z kwerendy wykonanej w Państwowym Archiwum Obwodu Lwowskiego wynika, że Kongregacja Kupiecka zaktywizowała swoją działalność tuż po wojnach: światowej i polsko-ukraińskiej. W czerwcu 1920 roku 53 członków Kongregacji ustanowiło zmianę statutu ${ }^{20}$, nawiązując przy tym do austriackiej ustawy o stowarzyszeniach niepolitycznych z 15 listopada $1867 \mathrm{roku}^{21}$. Ponownej jego modyfikacji dokonano, przy akceptacji Urzędu Wojewódzkiego we Lwowie, w $1922 \mathrm{roku}^{22}$. W pierwszych latach międzywojnia Kongregacja skupiała zaledwie kilkudziesięciu lwowskich kupców (zob. aneks 1), co powodowało niedogodności i było przedmiotem troski ówczesnych władz Kongregacji. Jeszcze we wrześniu 1923 roku, podczas Walnego Zgromadzenia, podnoszono ten problem publicznie $^{23}$. Ścisłe kierownictwo LKK w tamtym czasie tworzyli Jan Sudhoff (prezes) i Józef Litwinowicz (I wiceprezes), a ponadto: Jan Bujak (IV wiceprezes), Józef Halski, Edward Hawranek, Ludwik Hoszowski, Karol Krupiński, Jan Kadernożka (sekretarz), Kazimierz Maksymowicz (III wiceprezes), Stanisław Motylewski, Antoni Pawłowski (skarbnik), Jan Pawłowski, Edmund Riedl (zastępca sekretarza), Tadeusz Witek (zastępca skarbnika) i Stanisław Wagner ${ }^{24}$. Wraz z upływem czasu jej szeregi zaczęły się rozrastać. $Z$ treści korespondencji prowadzonej przez sekretariat LKK ze Starostwem grodzkim we Lwowie wynika, że w 1934 roku przynależność do niej deklarowało 300 osób. W tamtym czasie na czele Kongregacji stał Jan Kanty Pfau jako prezes. Do grona jego zastępców należeli: Julian Schayer, Kazimierz Maksymowicz oraz Stanisław Kistryn (zob. aneks 2).

Na przełomie 1937 i 1938 roku liczba członków LKK wynosiła już 1059. Wielu spośród członków Kongregacji mieszkało i prowadziło swoją działalność handlową poza Lwowem. Z lektury ankiety przygotowanej dla Głównego Urzędu Statystycznego w 1932 roku wynika, że do LKK (poza lwowianami) wstępowali również mieszkańcy: Bolechowa, Drohobycza, Dukli, Przemyśla, Stanisławowa, Stryja, Tarnopola, Trembowli oraz Truskawca ${ }^{25}$. W 1934 roku swój akces do LKK zgłosili kupcy przemyscy, którzy również utworzyli w terenie własne przedstawicielstwo ${ }^{26}$. Po 1937 roku

19 DALO, f. 1, op. 54, spr. 2115, s. 123; zob. także A. Biedrzy cka, op. cit., s. 409.

${ }^{20}$ DALO, f. 1, op. 54, spr. 2176, k. 44.

${ }^{21}$ Ibidem, k. 45, 84.

${ }^{22}$ DALO, f. 1, op. 54, spr. 2176, k. 47, 64, 80.

${ }^{23}$ CDIAL, f. 702, op. 1, spr. 35, k. 1.

${ }^{24}$ Ibidem, k. 3-4.

${ }^{25}$ CDIAL, f. 702, op. 1., spr. 15, k. 17. W latach 1926-1929 do LKK należało 38 kupców spoza Lwowa. Byli to mieszkańcy Brzeżan, Drohobycza, Kołomyi, Jaworowa, Rohatyna, Sambora oraz Tarnopola. A. Bezsmertnyj, Lwowskie organizacje kupieckie..., s. 370.

${ }^{26}$ E. Wygonik-Barzyk, op. cit., s. 161. 
część kupców zaczęła się organizować w zamiejscowych oddziałach Kongregacji. Wiadomo, że zakładano je w Buczaczu, w Horodence oraz w Kałuszu ${ }^{27}$. O ekspansji lwowskiej Kongregacji na obszarze Wschodniej Małopolski świadczy fakt, że jeszcze w lutym 1939 roku powołano do istnienia borysławski oddział Kongregacji (dokładna nazwa organizacji brzmiała: „Lwowska Kongregacja Kupiecka oddział w Borysławiu") ${ }^{28}$. Stosowną decyzję w tej sprawie wydało Starostwo drohobyckie 21 lutego 1939 roku. Kupcy borysławscy, tworząc swoje struktury, sięgnęli po statut LKK z 1922 roku. Animatorem borysławskiego oddziału był Wacław Ostrowski ${ }^{29}$.

O „członkostwo rzeczywiste” w Kongregacji mogli się ubiegać przede wszystkim chrześcijańscy właściciele, współwłaściciele i dzierżawcy „przemysłu handlowego” działającego we Lwowie. Prawo pierwszeństwa do przyjęcia mieli członkowie Stowarzyszenia Wzajemnej Pomocy Kupców i Młodzieży Handlowej, oczywiście pod warunkiem spełnienia wspomnianych wymogów. Ponadto dopuszczano możliwość przyjęcia do Kongregacji reprezentantów spółek handlowych cieszących się nieposzlakowaną opinią w społeczeństwie ${ }^{30}$.

Kupcom zrzeszonym w organizacji przysługiwały liczne przywileje. Wśród nich były między innymi możliwość korzystania z Funduszu Wzajemnej Doraźnej Pomocy, który wspierał rodziny zmarłych członków Kongregacjii ${ }^{31}$. Jak wynika z lektury „Kupca Polskiego”, w 1934 roku w celu zwiększenia dostępności do ubezpieczeń oferowanych przez Fundusz Wzajemnej Doraźnej Pomocy wysokość składek na wypadek śmierci zmniejszono z 5 do 3 złotych $^{32}$. Ideą przyświecającą założeniu tego Funduszu było przyznanie kupcom gwarancji ubezpieczeniowych, podobnych do tych, jakie przysługiwały pracownikom firm państwowych oraz samorządowych. LKK, realizując tę koncepcję, posiłkowała się zresztą podobnymi rozwiązaniami, jakie zastosowała wcześniej Izba Przemysłowo-Handlowa we Lwowie ${ }^{33}$. W przypadku Izby wysokość zasiłku dla rodziny zmarłego kupca oscylowała nawet w okolicach 1000 złotych.

W tym miejscu należy zaznaczyć, że każdorazowo osoba chcąca przystąpić do Kongregacji musiała uiścić wpisowe w wysokości 15 złotych (stan na 1934 r.). Składka miesięczna od jednego członka wynosiła z kolei 4,5 złotego. W zamian co dwa tygodnie przekazywano nieodpłatnie „Kupca Polskiego” - organ prasowy obu małopolskich kongregacji, krakowskiej i lwowskiej ${ }^{34}$.

${ }^{27}$ CDIAL, f. 702 , op. 1 , spr. 29, k. 1; CDIAL, f. 702, op. 1, spr. 31, k. 5.

${ }^{28}$ DALO, f. 1 , op. 54 , spr. 350, k. 1.

${ }^{29}$ Ibidem.

${ }_{30} \S 7$ Statutu Kongregacyi Kupieckiej we Lwowie, s. 5-6. Statut znajduje się w zbiorach Państwowego Archiwum Obwodu Lwowskiego. Zob. DALO, f. 1, op. 54, spr. 2176, k. 6.

${ }^{31}$ CDIAL, f. 702, op. 1, spr. 24, k. 6.

32 „Kupiec Polski. Organ Krakowskiej i Lwowskiej Kongregacji Kupieckiej”, R. XVII, nr 1-2, 1-15 I 1934, s. 9.

${ }^{33} \mathrm{Na}$ temat działalności lwowskiej Izby Przemysłowo-Handlowej w okresie międzywojennym więcej pisał Roman Masyk (Роман Масик) w artykule pt. Промислово-торгова палата у Львові y міжвоєнний період, „Наукові зошити історичного факультету Львівського університету” 2015, Випуск 16, s. 205-220.

${ }^{34}$ CDIAL, f. 702, op. 1, spr. 24, k. 6. 
W latach 30. struktura organizacyjna lwowskiej Kongregacji składała się z Wydziału, trzech sekcji (papiernicza, spożywcza i szkolna) ${ }^{35}$ i tyleż samo komisji (zakładania sklepów, kredytowej oraz Funduszu im. Zaremby). Największą aktywnością wykazywała się Komisja kredytowa, co też nie powinno dziwić, ze względu na wagę problematyki będącej w jej kompetencji ${ }^{36}$. W 1931 roku LKK rozpoczęła współpracę ze swoją krakowską odpowiedniczką przy wydawaniu branżowego, wspomnianego wcześniej, periodyku zatytułowanego „Kupiec Polski” ${ }^{37}$. Na jego łamach przede wszystkim skupiano się na problemach polskiego kupiectwa. Należy przy tym zaznaczyć, że w dwutygodniku dominowały informacje pochodzące z obszaru i kierownictwa Krakowskiej Kongregacji Kupieckiej.

Warto także odnotować, że pierwsza, prowizoryczna, siedziba LKK znajdowała się w lokalu przy ulicy Czarneckiego 1, w dotychczasowej siedzibie Stowarzyszenia Wzajemnej Pomocy Kupców i Młodzieży Handlowej we Lwowie ${ }^{38}$. W latach 20. Kongregacja mieściła się w budynku przy ulicy Halickiej 1939. Z kolei w 1934 roku dla biura LKK znaleziono nową lokalizację, a mianowicie pomieszczenia na drugim piętrze kamienicy przy ówczesnym Placu Bernardyńskim $2^{40}$. Z czasem przeniesiono je do budynku przy ulicy Piłsudskiego 11 (wcześniej noszącej nazwę ulicy Pańskiej) ${ }^{41}$.

\section{POLITYKA GOSPODARCZA I INFORMACYJNA}

Zasadniczą ideą towarzyszącą kupcom zrzeszonym pod szyldem Lwowskiej Kongregacji Kupieckiej była konsolidacja kupiectwa chrześcijańskiego, co w praktyce zazwyczaj oznaczało zwalczanie konkurencji reprezentowanej przez kupców żydowskich ${ }^{42}$. W pierwszych latach istnienia Kongregacji - pomimo usilnych prób nie udało się w pełni zrealizować postulatu zjednoczenia chrześcijańskich (polskich) stowarzyszeń kupieckich we Lwowie ${ }^{43}$. Na realizację tego planu trzeba było czekać

${ }^{35}$ Jeszcze w 1932 r. Kongregacja Kupiecka we Lwowie składała się z czterech sekcji: bławatno-sukienniczej, papierniczej, drogeryjno-perfumowej i spożywczej. Najsilniej reprezentowana była ostatnia z wymienionych. W jej składzie zasiadało 63 członków Kongregacji. Dla porównania w najsłabiej reprezentowanych sekcjach (drogeryjno-perfumowej oraz papierniczej) znajdowało się po 13 osób. CDIAL, f. 702 , op. 1 , spr. 15, k. 17.

${ }^{36}$ CDIAL, f. 702 , op. 1 , spr. 29 , k. 26.

${ }^{37}$ E. Wygonik-Barzyk, op. cit., s. 112.

38 Skorowidz Przemystowo-Handlowy..., s. 182, 184.

${ }^{39}$ CDIAL, f. 702 , op. 1 , spr. 8, k. 5.

${ }^{40}$ DALO, f. 1, op. 54, spr. 2176, k. 104.

${ }^{41}$ CDIAL, f. 702, op. 1, spr. 29, k. 6.

$42 \S 4$ Statutu Kongregacyi Kupieckiej we Lwowie (DALO, f. 1, op. 54, spr. 2176, k. 4); zob. też A. Biedrzycka, op. cit., s. 884 .

${ }^{43} \mathrm{~W}$ latach 20. XX w. we Lwowie istniały cztery organizacje zrzeszające kupców rzymskokatolickich: Kongregacja Kupiecka, Stowarzyszenie Kupców i Młodzieży Handlowej, Stowarzyszenie Drobnych Kupców Chrześcijańskich oraz lwowski oddział Stowarzyszenia Kupców Polskich z siedzibą 
do 1929 roku. Wówczas podjęto starania o przyłączenie do Kongregacji kupców chrześcijańskich zrzeszonych dotychczas w Stowarzyszeniu Kupców Polskich w Warszawie Oddział we Lwowie ${ }^{44}$, przy czym należy zaznaczyć, że w tym samym czasie lwowska Kongregacja podlegała strukturom Naczelnej Rady Zrzeszeń Kupiectwa Polskiego z siedzibą w Warszawie ${ }^{45}$.

Kongregacja prowadziła również działalność informacyjną w sprawie ewentualnych propozycji kontraktów dla przedsiębiorstw handlowych zrzeszonych w jej strukturach. Z taką sytuacją spotykamy się w październiku 1929 oraz w maju 1933 roku, kiedy to radni miejscy Lwowa podjęli uchwałę o zaopatrzeniu Miejskich Zakładów Opieki nad Dziećmi. W celu realizacji intratnego zamówienia zwrócono się między innymi do Kongregacji Kupieckiej, aby ta zechciała powiadomić swoich członków o zorganizowanym przetargu ${ }^{46}$.

W kategorii działalności informacyjnej Kongregacji należy traktować także udział w procesie wydawniczym czasopisma kupieckiego zatytułowanego „Kupiec Polski". Partnerem lwowian w przygotowywaniu tego czasopisma była Krakowska Kongregacja Kupiecka, która już w 1907 roku zainicjowała wydawanie tego tytułu w Galicji ${ }^{47}$. Po trudach związanych z opłacalnością przedsięwzięcia tytuł zamknięto tuż przed I wojną światową, aby go reaktywować w Krakowie w 1925 roku. Początki współpracy kupców krakowskich i lwowskich w obrębie „Kupca Polskiego” sięgają 1931 roku, kiedy - nie bez komplikacji - udało się wypracować zasady związane z tym przedsięwzięciem ${ }^{48}$. Początkowo wydawnictwo to kolportowano wśród członków obu kongregacji nieodpłatnie. Od stycznia 1933 roku uchwałą Walnego Zgromadzenia Kongregacji Kupieckiej we Lwowie kupców w niej zrzeszonych zobligowano do częściowego ponoszenia kosztów druku czasopisma ${ }^{49}$. Wysokość dodatkowej opłaty wyniosła 50 groszy w skali miesiąca. W celu zwiększenia skuteczności ściągania tej kwoty ustalono, że zostanie ona doliczona do obowiązkowej składki członkowskiej ${ }^{50}$.

Niewątpliwą ciekawostką pozostaje fakt, że władze LKK prowadziły monitoring prasy. W 1923 roku po niepochlebnych publikacjach w prasie na temat chrześcijańskich kupców powołano specjalną komisję mającą za zadanie reagować według możliwości na podobne artykuły. Wyszukiwano drukowanych informacji na temat Kongregacji i w ogóle chrześcijańskiego kupiectwa we Lwowie. Z jakim skutkiem

\footnotetext{
w Warszawie. To ostatnie zresztą zrzeszało również przedstawicieli sektora przemysłowego i bankowego, co podnoszono w trakcie Walnego Zgromadzenia LKK we wrześniu 1923 r. W 1923 r. rozważano także możliwość połączenia się lwowskiej Kongregacji z lwowskim oddziałem Stowarzyszeniem Kupców Polskich. Projekt ten jednak nie znalazł akceptacji członków KK. Warto wspomnieć, że własną organizację mieli także kupcy ukraińscy (greckokatoliccy). Był to założony w 1923 r. Sojusz Ukraińskich Kupców. CDIAL, f. 702, op. 1, spr. 35, k. 1-2, 6-9; ibidem, f. 702, op. 1, spr. 8, k. 50-51.

${ }^{44}$ CDIAL, f. 702, op. 1, spr. 8, k. 20.

${ }^{45}$ CDIAL, f. 702 , op. 1 , spr. 15 , k. 17.

${ }^{46}$ CDIAL, f. 702, op. 1, spr. 16, k. 7; CDIAL, f. 702, op. 1, spr. 34.

${ }^{47}$ E. Wygonik-Barzyk, op. cit., s. 86.

${ }^{48}$ Ibidem, s. 112.

${ }^{49}$ CDIAL, f. 702 , op. 1 , spr. 16 , k. 36.

${ }^{50}$ Ibidem.
} 
się to odbywało? Trudno jednoznacznie wskazać. Inicjatorem pomysłu był Józef Halski. W skład tego gremium, poza Halskim, wchodzili Józef Litwinowicz i Leon Skrzypek ${ }^{51}$.

Nieoceniona okazywała się pomoc Kongregacji w pozyskiwaniu partnerów handlowych z innych państw. Na przykład w 1933 roku Prezydium LKK kilkakrotnie zachęcało do podjęcia współpracy z firmami czechosłowackimi reprezentującymi różnorodne branże, od maszynowej począwszy, a na medycznej skończywszy ${ }^{52}$. Dwa lata później, w 1934 roku, za pośrednictwem Kongregacji, Polsko-Austriacka Izba Handlowa prowadziła kampanię mającą na celu wzrost obrotów handlowych pomiędzy Austrią i Polską. W tym celu do siedziby LKK przesyłano wykazy firm austriackich zainteresowanych rozwinięciem kontaktów gospodarczych z polskimi przedsiębiorcami ${ }^{53}$. Ponadto $\mathrm{w}$ celu powiększenia rynku zbytu oraz wzmocnienia pozycji swoich członków na rynkach ponadlokalnych władze Kongregacji w 1933 roku zdecydowały się przystąpić do „Małopolskiego Towarzystwa Handlu Wymiennego (Kompensacyjnego) Spółka z ogr. odp. we Lwowie" ${ }^{44}$.

Kongregacja odpowiadała również na bieżące problemy kupiectwa lwowskiego. W latach powojennych, kiedy gospodarki państw europejskich, w tym też odrodzonej Polski, znalazły się w depresji ekonomicznej, dążono do zmniejszenia obciążeń fiskalnych kupców. Planowano to osiągnąć, wpływając na rząd, aby ten dokonał zmiany podatku dochodowego ${ }^{55}$. Reagowano także w sprawach wywołanych nagłymi okolicznościami. Znamienny przykład stanowi sytuacja zaistniała na przełomie 1928/1929 roku. Wówczas z powodu ostrych mrozów i gwałtownych śnieżyc nastąpił paraliż komunikacyjny w województwie lwowskim, w wyniku czego drastycznie spadły obroty handlowe miejscowych kupców, co w konsekwencji doprowadziło do utraty płynności finansowej wielu z nich. To z kolei spowodowało zaprzestanie spłacania należnych zobowiązań względem Banku Polskiego. Dyrekcja tego ostatniego postanowiła umieszczać „nierzetelnych” kupców na czarnej liście kredytobiorców. Prezydium Kongregacji interweniowało w tej sprawie we lwowskiej Izbie Przemysłowo-Handlowej. Proszono jej władze, aby wynegocjowały w kierownictwie miejscowego oddziału Banku Polskiego liberalne potraktowanie doświadczonych przez żywioł kupców ${ }^{56}$.

Problem niewypłacalności części lwowskich kupców zrzeszonych w Kongregacji pojawiał się również w latach późniejszych. Dotykało to przede wszystkim pożyczkobiorców korzystających z Funduszu Otwierania Sklepów działającego przy LKK i oferującego preferencyjne kredyty dla osób do niego przynależących. Dla wielu lwowskich przedsiębiorców fundusz ten okazał się zbawienny w czasie trwania kryzysu ekonomicznego. Niestety niektórzy jego beneficjenci nie wywiązywali

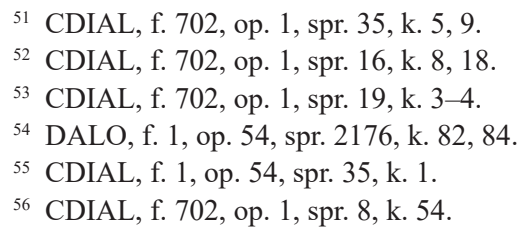


się ze spłaty swoich zobowiązań kredytowych ${ }^{57}$. Tym sposobem Fundusz narażono na utratę płynności finansowej. W celu uniknięcia tego czarnego scenariusza systematycznie podnoszono jego kapita ${ }^{58}$. Wystarczy wskazać, że w okresie od 1928 do 1937 roku wzrósł on z niespełna 34 tysięcy do prawie 50 tysięcy złotych. Stosowny program naprawczy mający zdyscyplinować niesumiennych kredytobiorców próbowano wdrożyć w 1937 roku. Jednym z pomysłów było upublicznienie na forum Walnego Zgromadzenia LKK nazwisk kupców niespłacających swoich zobowiązań względem instytucji. Inicjatywa ta nie spotkała się jednak ze zrozumieniem kierownictwa Kongregacji. Wiadomo, że próbowano wystąpić „znacznie energiczniej” względem opieszałych dłużników, którzy nie spłacali kredytów wyłącznie z własnej winy ${ }^{59}$. Niemniej nie mam wiedzy, jakie szczegółowe kroki podjęto w tej sprawie. Konkludując rozważania na temat Funduszu Otwierania Sklepów, warto zaznaczyć, że w 1937 roku z kredytów oferowanych przez LKK korzystało łącznie 39 chrześcijańskich kupców. Ogółem pożyczona kwota wyniosła wówczas niespełna 40 tysięcy złotych ${ }^{60}$.

W latach 30. XX wieku Kongregacja stanęła przed nie lada wyzwaniem. Pogłębiający się ogólnoświatowy kryzys ekonomiczny oraz postępująca stagnacja gospodarcza zmusiły władze LKK do podejmowania trudnych decyzji. Pierwszym symptomem postępującego regresu było wycofanie się w 1929 roku lwowskiej kongregacji z finansowego wspierania organizacji Targów Wschodnich ${ }^{61}$. Warto jednak zauważyć, że lata kryzysu nie wpłynęły zbyt negatywnie na stan majątku Kongregacji, czego dowodzą dane zamieszczone w tabeli 1 .

Tabela 1. Stan finansów i majątku Lwowskiej Kongregacji Kupieckiej w latach 1928-1937 [zł]

\begin{tabular}{|c|c|c|c|}
\hline Fundusz / Majątek & $\mathbf{3 1}$ XII 1928 & $\mathbf{3 1}$ XII 1933 & 31 XII 1937 \\
\hline Fundusz żelazny & 615,30 & 1841 & 3999,98 \\
\hline Fundusz Wzajemnej Doraźnej Pomocy & 2673,42 & 6800 & 7888 \\
\hline Fundusz Pożyczkowy & 33996,52 & 43117 & 49758 \\
\hline Inwentarz własny (ruchomości) & 118,02 & 668,42 & 3849 \\
\hline Fundusz Własnego Domu & - & - & 40424,83 \\
\hline Ogółem & 37403,26 & 52426,42 & 105919,82 \\
\hline
\end{tabular}

Źródło: CDIAL, f. 702, op. 1, spr. 31, k. 6.

${ }^{57}$ CDIAL, f. 702 , op. 1 , spr. 30, s. 3; CDIAL, f. 702, op. 1, spr. 31, k. 3-4.

${ }_{58}$ Środki finansowe na wsparcie polityki kredytowej lwowskiej Kongregacji pochodziły z pożyczki zaciągniętej na przełomie X i XI 1936 r. Jej wysokość wynosiła 100 tys. złotych. CDIAL, f. 702, op. 1, spr. 29, k. 14.

${ }^{59}$ CDIAL, f. 702 , op. 1 , spr. 31 , k. 4.

${ }^{60}$ Ibidem.

${ }^{61}$ Apel w tej sprawie do Kongregacji wystosował na przełomie VIII i IX 1929 r. pełniący wówczas obowiązki Prezydenta Lwowa zastępca komisarza rządowego Roman Frankowski, jednocześnie będący przewodniczącym Komitetu Organizacyjnego Targów. CDIAL, f. 702, op. 1, spr. 8, k. 35. 
Z informacji zaprezentowanych w tabeli wynika, że o ile jeszcze w 1928 roku całkowity majątek Kongregacji wynosił nieco ponad 37403 złote, o tyle pięć lat później kwota ta wzrosła do 52 426. Po dziewięciu latach oszacowano go już na niespełna 106 tysięcy złotych. Tym sposobem w grudniu 1937 roku odnotowujemy przyrost majątku i funduszy Kongregacji o około 65\% w stosunku do roku 1928. Jak widać, Kongregacja w latach 1928-1937 podniosła wartość swojego majątku, aczkolwiek należy pamiętać, że przynajmniej częściowo zjawisko to było konsekwencją wzrostu inflacji. W przypadku funduszu pożyczkowego decyzja o dokapitalizowaniu została wymuszona niską ściągalnością udzielonych kredytów, o czym już wcześniej wspominałem.

Bardzo silnie reprezentowani w Kongregacji byli przedsiębiorcy trudniący się handlem towarami kolonialnymi. Na ich potrzeby powstała nawet Sekcja Kolonialno-Spożywcza, gdzie dyskutowano nad rozwiązaniami mającymi poprawić popyt na produkty oferowane przez sklepy i składy kolonialne. Co ciekawe, działania wspomnianej sekcji wychodziły poza sferę debat oraz spekulacji i miały wymierny charakter. Na przykład u schyłku lat 30. udało się wypracować wspólne stanowisko odnośnie do podniesienia rabatów na wyroby tytoniowe ${ }^{62}$.

W kompetencji LKK pozostawało także prowadzenie polityki informacyjnej względem swoich członków. Tym sposobem Kongregacja stawała się platformą komunikacji pomiędzy organami administracji państwowej a kupiectwem chrześcijańskim skupionym w południowo-wschodnich województwach II RP. Kolportowane za pomocą okólników informacje dotyczyły zazwyczaj wdrażanych przepisów prawnych dotyczących handlu i spraw pokrewnych. Na przykład w okólniku z 22 października 1936 roku donoszono o potrzebie „umieszczania cenników możliwie obszernych i dokładnych w miejscu widocznym w sklepie" czy też o konieczności „oznaczania towarów cenami sprzedaży tak wewnątrz jak i na wystawach" ${ }^{63}$. Innym razem Kongregacja w porozumieniu z Głównym Urzędem Statystycznym uczestniczyła w akcji zbierania ankiet „o wolnych zrzeszeniach kupieckich”. W jej ramach poproszono kupców należących do LKK o uzupełnienie stosownych kwestionariuszy i przesłanie ich do marca 1932 roku do siedziby Głównego Urzędu Statystycznego, co też uczyniono ${ }^{64}$.

Fundamentalnym zadaniem Kongregacji było ułatwienie operacji handlowych swoim członkom. Temu też służyła promocja transakcji finansowych za pomocą operacji bezgotówkowych, przy użyciu czeków. Jak słusznie informowano w okólniku Kongregacji z 22 grudnia 1932 roku: „Korzyści płynące z przystąpienia do obrotu czekowego jak: szybkość, taniość, wygoda są ogólnie znane. W interesie zatem własnym kupiectwa leży przystąpienie do obrotu czekowego i to o ile możliwości jak najrychlej, a to ze względu na spodziewaną znaczną ilość zgłoszeń [...]”65. Przypuszczalnie władze Kongregacji miały udział w uruchomieniu przy lwowskim oddziale

\footnotetext{
${ }^{62}$ CDIAL, f. 702, op. 1, spr. 30, s. 3.

63 CDIAL, f. 702, op. 1, spr. 29, k. 17.

${ }^{64}$ CDIAL, f. 702, op. 1, spr. 15, k. 13-14.

65 CDIAL, f. 702 , op. 1, spr. 16, k. 38.
} 
Pocztowej Kasy Oszczędności - wówczas zlokalizowanym przy ulicy Trzeciego Maja 9 - usług związanych z realizacją transakcji czekowych ${ }^{66}$.

Do Kongregacji często zwracano się z prośbą o opiniowanie rozwiązań prawnych dotyczących kwestii handlowych. Potwierdzeniem tej opinii może być pismo wystosowane przez Juliana Schayera - wiceprezesa lwowskiej Izby Przemysłowo-Handlowej z 25 kwietnia 1935 roku do władz LKK, w którym prosił o „,nadsyłanie cennych uwag” odnośnie do planowanej reformy wówczas „obowiązującego systemu świadectw przemysłowych" ${ }^{\prime 67}$.

Ciekawostką pozostaje fakt, że najprawdopodobniej władze LKK angażowały się również w rozwój i promocję międzywojennego przemysłu kinematograficznego. Zachowana dokumentacja archiwalna nie pozwala jednoznacznie stwierdzić, jaka była rola Kongregacji w tym procesie, aczkolwiek można wnioskować, że jej członkowie próbowali doprowadzić do poprawy kondycji sektora filmowego w II Rzeczypospolitej lub przynajmniej stale go monitorowali. Powyższą opinię buduję na podstawie odnalezionego w zespole archiwalnym o nazwie „Lwowska Kongregacja Kupiecka" dokumentu zawierającego skrupulatnie i kompetentnie przygotowaną charakterystykę przemysłu filmowego w Polsce wraz z jego słabymi stronami. $\mathrm{W}$ piśmie tym wskazywano wręcz na swoisty marazm przejawiający się w tej branży, w wyniku czego rocznie powstawało zaledwie 5-10 filmów rodzimej produkcji, co pozostawało w sprzeczności z rosnącym zapotrzebowaniem i oczekiwaniami klientów/widzów. Powstałej luki nie zapełniały filmy zagraniczne, gdyż nabywanie praw do ich projekcji było mało opłacalne, więc w rezultacie prowincjonalne kina zostały skazane na wegetację. Wśród przyczyn takiego stanu rzeczy autorzy raportu przedstawionego do wiadomości LKK dopatrywali się między innymi w wysokich cłach na filmy zagraniczne sprowadzane do Polski ${ }^{68}$. Ponadto przestarzałe regulacje prawne pochodzące z okresu rozbiorowego powodowały, że wytwórnie filmowe oraz wypożyczalnie działały na mocy prawa patentowego, a z kolei wypożyczalnie filmów kinowych na podstawie udzielonych licencji. Tych ostatnich funkcjonowało zresztą na terenie Polski zaledwie 25, z czego aż $15 \mathrm{w}$ Warszawie - siedzibie Ministerstwa Spraw Wewnętrznych odpowiedzialnego za cenzurę filmową (właściwa agenda nosiła nazwę Centralne Biuro Filmowe) ${ }^{69}$. Mankamentem działających na terenie Polski kinoteatrów pozostawała słaba sieć dystrybucji filmów zagranicznych. Niektóre międzynarodowe wytwórnie, jak Goldwyn, Metro, Fox, National, United Artists czy Paramount rozpowszechniały swoje filmy, pominąwszy rynek polski, przyczyniając się tym sposobem do realnych strat dla przedsiębiorców trudniących się tym przemysłem $^{70}$. Remedium na bolączki polskiej kinematografii miało być utworzenie

${ }^{66}$ Przed 1933 r. lwowscy kupcy chcący korzystać z operacji czekowej byli zmuszeni posiadać stosowne konto w centrali Pocztowej Kasy Oszczędności w Warszawie. CDIAL, f. 702, op. 1, spr. 16, k. 38.

${ }^{67}$ CDIAL, f. 702, op. 1, spr. 26, k. 13.

${ }^{68}$ CDIAL, f. 702, op. 1, spr. 33, s. 1.

${ }^{69}$ Ibidem; por. też R. Włodek, „Patrz Kościuszko, na nas z”... ekranu. Obraz Naczelnika w filmie [w:] Społeczeństwo - Kultura - Inteligencja. Studia Historyczne ofiarowane Profesor Irenie Homoli-Skapskiej, red. E. Orman, G. Ni eć, Kraków-Warszawa 2009, s. 559.

${ }^{70}$ CDIAL, f. 702, op. 1, spr. 33, s. 1. 
firmy odpowiedzialnej za dystrybucję filmów we współpracy z jedną z amerykańskich wytwórni, mającej statut światowego potentata w branży filmowej. Trzon tego przedsiębiorstwa miała stanowić agencja filmowa Corso, która - obok Warszawy czy Łodzi - posiadała swoje kinoteatry także w Małopolsce Wschodniej (Stanisławów kino Urania; oraz kino Sztuka w Drohobyczu $)^{71}$. Z tego też powodu najpewniej o planach modernizacji sieci dystrybucyjnej filmów na terenie kraju informowano władze LKK. Trudno jednoznacznie ocenić, czy i jaki miał być udział lwowian w tym przedsięwzięciu. Analiza kosztorysu pozwala domniemywać, że działalnością nowej firmy planowano objąć Lwów, stąd też mogła wynikać niejako próba pozyskania kierownictwa Kongregacji we Lwowie dla nowej inicjatywy. Dziś nie sposób przekonująco stwierdzić, jak potoczyły się losy projektu, niemniej jak widać z powyższego aktywność LKK wybiegała daleko poza działalność handlową sensu stricto.

\section{POLITYKA OŚWIATOWA}

Jedną z najważniejszych płaszczyzn działalności lwowskiej Kongregacji pozostawała organizacja edukacji o profilu handlowym. Sztandarowym projektem LKK w dziedzinie oświaty było utworzenie Szkoły Handlowej Dokształcającej Kongregacji Kupieckiej. Powstała ona w 1929 roku $^{72}$. Jej siedziba mieściła się we Lwowie przy ulicy Bourlarda 5. Wśród czynników, które przyczyniły się do utworzenia szkoły, znalazło się rosnące zapotrzebowanie młodzieży na kształcenie się w zawodzie kupieckim. W opinii ówczesnych władz Kongregacji dotychczas publiczna szkoła handlowa działająca przy ulicy Skarbkowskiej nie gwarantowała przyjęcia wszystkich chętnych. Ponadto chrześcijańscy kupcy uznali za stosowne mieć wpływ na nauczane treści i kształtowanie poglądów uczniów, gdyż, jak stwierdzono, „różnorodne otoczenie [dotychczasowej szkoły handlowej - przyp. K.M.] nie [...] [dawało] gwarancji należytego wychowania"73. Warto zauważyć, że ukończenie trzech klas wspomnianej szkoły dokształcającej (lub innej równorzędnej), z co najmniej wynikiem dostatecznym, dawało gwarancję zdobycia uprawnień do pracy w zawodzie kupieckim na stanowisku pomocnika handlowego ${ }^{74}$. Przy czym wraz z finalizacją edukacji teoretycznej od ucznia żądano odbycia równolegle trzyletniej praktyki zawodowej

${ }^{71}$ Ibidem, s. 1-3.

${ }^{72}$ CDIAL, f. 702 , op. 1 , spr. 30, k. 2.

${ }^{73}$ CDIAL, f. 702, op. 1, spr. 8, k. 48.

${ }^{74}$ CDIAL, f. 702, op. 1, spr. 25, k. 2. Warto zauważyć, że wraz z upływem czasu doszło do rywalizacji pomiędzy wspomnianymi szkołami. W VII 1933 r. władze Publicznej Szkoły Dokształcającej wystosowały nawet do kupców zrzeszonych na terenie Lwowa monit przypominający o obowiązku uczęszczania do tej placówki wszystkich praktykantów handlowych, pod rygorem powiadomienia inspektora pracy. Zawiadomienie to wywołało stosowną reakcję kierownictwa Kongregacji, które wezwało do zbagatelizowania tego pisma, argumentując tę decyzję, że „członkowie Kongregacji Kupieckiej mają moralny obowiązek posyłania swoich praktykantów do własnej szkoły”. CDIAL, f. 702, op. 1, spr. 16, k. 22. 
w wybranym punkcie handlowym ${ }^{75}$. Po zakończeniu terminowania praktykant otrzymywał dyplom poświadczający zdobyte wykształcenie i był wpisywany do księgi zawodowych kupców prowadzonej przez $\mathrm{LKK}^{76}$. O nadanie przywileju wnioskował właściciel przedsiębiorstwa zapewniającego naukę praktyczną zawodu ${ }^{77}$. Zdarzały się również przypadki, kiedy to władze Kongregacji występowały z prośbą o przyjęcie ucznia na praktykę do konkretnego przedsiębiorstwa handlowego ${ }^{78}$. Praktyki organizowane pod auspicjami LKK cechowała każdorazowo przygotowywana umowa, którą zawierał właściciel przedsiębiorstwa oferującego praktykę oraz prawny opiekun ucznia, jeśli ten był nieletni ${ }^{79}$.

Niestety warunki panujące w szkole i jakość oferowanej edukacji pozostawiały wiele do życzenia. Chroniczne niedofinansowanie placówki skutkowało między innymi brakiem podręczników przeznaczonych dla ubogich uczniów. Subwencje otrzymywane z Ministerstwa Oświaty i Wyznania Publicznego pokrywały zaledwie najważniejsze wydatki ${ }^{80}$. W trakcie przeprowadzonej w maju wizytacji stwierdzono, że „nauka odbywa się normalnie, choć niepunktualnie [...]”"1. Liczba uczniów uczęszczających w tym czasie do szkoły wynosiła 74, przy czym frekwencja oscylowała na poziomie $80 \%$. Niestety wszelkie pomoce uczniowskie nadal ograniczone były do niezbędnego minimum. $Z$ tego też powodu w grudniu 1929 roku zwrócono się z prośbą do stowarzyszenia Wzajemnej Pomocy Kupców i Młodzieży Handlowej, aby zechciało ono wesprzeć finansowo szkołę $e^{82}$. Niestety dostępne źródła archiwalne nie pozwalają jednoznacznie stwierdzić, czy taka pomoc nastąpiła. Po wspomnianej wizytacji wiele uwag kierowano pod adresem kierownika placówki Burnatowicza, któremu zarzucono między innymi brak energii i należnej estymy wśród podopiecznych i nauczycieli ${ }^{83}$. W 1933 roku szkoła uzyskała status placówki publicznej, dzięki czemu najprawdopodobniej udało się ją uratować. Niemniej władze LKK nadal ją wspierały, uważając Szkołę Handlową za zaplecze kupiectwa chrześcijańskiego nie tylko we Lwowie, ale i w całej Małopolsce Wschodniej ${ }^{84}$. Opiekę nad nią z ramienia Kongregacji sprawowała Sekcja Szkolna. Placówka otrzymywała również wsparcie ze strony miejscowej Izby Przemysłowo-Handlowej, co znalazło odzwierciedlenie

${ }^{75}$ CDIAL, f. 702 , op. 1 , spr. 25 , k. 7.

${ }^{76}$ CDIAL, f. 702 , op. 1 , spr. 24, k. 3; CDIAL, f. 702, op. 1, spr. 25, k. 7.

77 CDIAL, f. 702 , op. 1 , spr. 24, k. 5.

${ }^{78}$ CDIAL, f. 702 , op. 1 , spr. 25 , k. 6.

${ }^{79}$ Uczniowie poniżej 14. roku życia nie mogli być przyjmowani na praktykę. W przypadku gdyby nastąpiło złamanie tego przepisu, władze Kongregacji miały prawo nie wpisania go do księgi zawodowej kupców. Pełnoletność wyznaczał wiek 21 lat. W myśl rozporządzenia Prezydenta RP z dnia 6 VI 1927 r. o prawie przemysłowym (Dz.U. Nr 53, poz. 468) oraz na mocy Ustawy z 10 III 1934 r. (Dz.U. Nr 40, poz. 350) umowa pisemna dotycząca rozpoczęcia praktyki musiała być sporządzona i podpisana przed upływem czterech tygodni od momentu jej rozpoczęcia. CDIAL, f. 702, op. 1, spr. 25, k.2; CDIAL, f. 702 , op. 1 , spr. 26, k. 24.

${ }^{80}$ CDIAL, f. 702 , op. 1 , spr. 8 , k. 48.

${ }^{81}$ CDIAL, f. 702, op.1, spr. 8, k. 6.

82 Ibidem, k. 48.

${ }^{83}$ Ibidem, k. 6.

${ }^{84}$ CDIAL, f. 702 , op. 1, spr. 30, s. 2-3. 
w podziękowaniach kierowanych od władz LKK pod adresem tej instytucji ${ }^{85}$. W końcu lat 30. XX wieku szkoła zaczęła przeżywać swój renesans. W 1937 roku liczba uczniów obu płci uczęszczających do niej na naukę sięgnęła 330, a więc odnotowano pięciokrotny wzrost w porównaniu ze stanem z 1929 roku. Jako przyczyny sukcesu wskazywano podniesienie poziomu edukacji oraz poprawę w infrastrukturze dydaktycznej ${ }^{86}$.

Działalność kupców zrzeszonych w Kongregacji nie ograniczyła się wyłącznie do wspierania wspomnianej szkoły handlowej. W 1929 roku Prezydium Kongregacji pozytywnie zaopiniowało powołanie we Lwowie bursy przeznaczonej dla terminatorów i praktykantów handlowych. Ponadto władze LKK zachęcały swoich członków, aby wstępowali do Towarzystwa Wzorowej Bursy dla Terminatorów i Praktykantów Handlowych we Lwowie i tym samym przyczynili się do wsparcia tej inicjatywy ${ }^{87}$. $\mathrm{Z}$ treści zachowanych materiałów archiwalnych wynika, że choć kursy o profilu handlowym dominowały w ofercie Kongregacji, to nie były jedynymi. W okresie wakacyjnym uruchamiano również, trwające kilkanaście dni, kursy dekoratorskie ${ }^{88}$.

Władze lwowskiej Kongregacji dbały także o samokształcenie swoich członków i współpracowników. Z tego też powodu organizowano kursy handlowe, które przeprowadzano w pomieszczeniach należących do LKK. Zajęcia odbywały się w godzinach późnowieczornych trzy razy w tygodniu, w poniedziałki, środy i piątki. Udział w kursach nie był bezpłatny. Każdy zainteresowany został zobligowany do uiszczenia symbolicznej opłaty w wysokości trzech złotych ${ }^{89}$. Obok kursów handlowych Zarząd Kongregacji oferował również uczestnictwo w kursach dodatkowych, takich jak na przykład kurs dekoracji wystaw sklepowych, handlowy dla małorolnych czy rachunkowo-handlowy dla rzemieślników. Ten ostatni organizowano we współpracy z lwowską Izbą Rzemieślniczą. We Lwowie na szkolenia te przewidziano około dwóch miesięcy. Z kolei w miastach prowincjonalnych objętych zakresem działania Kongregacji edukacja taka trwała kilka dni. Inicjatywy te spotkały się z dużym zainteresowaniem. Ze sprawozdania LKK za rok 1937 wynika, że w kursach uczestniczyły osoby w wieku od 18. do 76. roku życia ${ }^{90}$.

\section{DZIAŁALNOŚĆ SPOŁECZNA I PATRIOTYCZNA}

Członkowie Lwowskiej Kongregacji Kupieckiej zaangażowani byli również w działalność na innych niż gospodarka płaszczyznach. Na przykład w lutym 1929 roku Prezydium Kongregacji zwróciło się z apelem do lwowskich kupców, aby

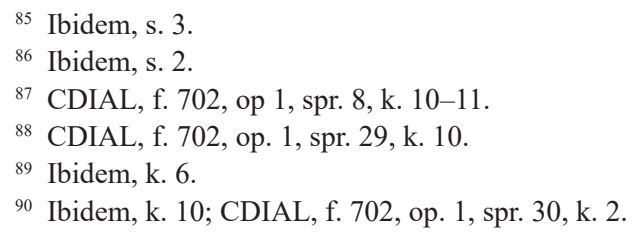


ci zechcieli przystąpić do Ligi Obrony Przeciwlotniczej i Przeciwgazowej (LOPP), argumentując swą prośbę w następujący sposób:

Doceniając wagi i znaczenia tego rodzaju organizacji, która oddaje niewysłowione wprost usługi społeczeństwu, współdziałając w rozwoju lotnictwa i przemysłu chemicznego, przygotowując [...] w sposób gruntowny obronę Państwa - zwracamy się do Szanownych Panów Kolegów o zadeklarowanie na załączonej liście Swego przystąpienia do Ligi, gdyż w ten sposób spełnimy swój obywatelski obowiązek.

Kupiectwo, które w swej ofiarności na rzecz Państwa zawsze przodowało i tym razem nie może pozostać w tyle poza innymi, zatem nie wątpimy, ani na chwilę, że w szeregach Ligi nikogo z Członków Kongregacji Kupieckiej nie zabraknie ${ }^{91}$.

Najprawdopodobniej członkowie Kongregacji przyjęli apel ze zrozumieniem i niektórzy z nich przystąpili do LOPP we Lwowie. Relacje łączące władze Kongregacji z Ligą były zażyłe, o czym świadczy między innymi przesłane w maju 1933 roku zaproszenie do uświetnienia we Lwowie dziesięciolecia wojewódzkich struktur Ligi ${ }^{92}$.

Członkowie Kongregacji nie ograniczyli się tylko do wspierania LOPP. We wrześniu 1933 roku jej władze nie omieszkały wziąć udziału w subskrybowaniu Pożyczki Narodowej rozpisanej przez Ministerstwo Skarbu ${ }^{93}$. W tym samym czasie angażowano się w prace na rzecz Koła Lwowskiego Związku Obrony Kresów Zachodnich, którego działalność skierowana była przeciwko polityce Niemiec wobec polskich mieszkańców Górnego Śląska i Pomorza oraz wszelkim przejawom separatyzmów na tym obszarze ${ }^{94}$. Z kolei trzy lata później, w październiku 1936 roku kierownictwo Kongregacji przyłączyło się do prowadzonej zbiórki na rzecz Funduszu Obrony Narodowej (FON). W tej sprawie wystosowało nawet „Odezwę do Kupiectwa chrześcijańskiego Małopolski Wschodniej”, w której zachęcano:

W poczuciu obowiązku obywatelskiego i wierne swym tradycjom kupiectwo chrześcijańskie staje do współpracy z armią w jej poczynania dla zagwarantowania pokoju i bezpieczeństwa. Utworzony przez wszystkie organizacje kupieckie wchodzące w skład Naczelnej Rady Zrzeszeń Kupiectwa Polskiego Komitet Główny Zbiórki Chrześcijańskiego Kupiectwa przystąpił do zbiórki dobrowolnych datków na F.O.N.

Wydział Kongregacji Kupieckiej wzywa ogół kupiectwa Lwowa i Małopolski Wschodniej do składania ofiar w PKO [...]. Ofiarodawcy otrzymują dyplom z Minist. Spr. Wojsk., a ponadto od Kupieckiego Komitetu Głównego ozdobne zaświadczenia, które umieszczone w lokalu przedsiębiorstwa będą oznaką, że dana firma chrześcijańska spełniła swój obowiązek wobec Państwa [...]. Wydział Kongregacji Kupieckiej wyraża nadzieję, że na listach ofiarodawców nie braknie ani jednej chrześcijańskiej firmy! ${ }^{95}$

Posłanie to sygnowali: prezes Kongregacji - Jan Kanty Pfau; wiceprezesi: Julian Schayer, Roman Gorgolewski i Mikołaj Olech; sekretarze Leon Skrzypek, Tadeusz

\footnotetext{
${ }^{91}$ CDIAL, f. 702, op. 1, spr. 8, k. 2.

92 CDIAL, f. 702 , op. 1, spr. 36, k. 36.

93 CDIAL, f. 702 , op. 1, spr. 16, k. 16.

94 CDIAL, f. 702, op. 1, spr. 36, k. 35.

95 CDIAL, f. 702, op. 1, spr. 29, k. 11.
} 
Cwetler oraz skarbnik Stanisław Czołowski ${ }^{96}$. Ponadto we wrześniu 1933 roku LKK wsparła ideę „pożyczki narodowej”. W tym też celu ustalono minimalne kwoty subskrypcji dla miejscowych kupców w wysokości od 50 do nawet 4000 złotych ${ }^{97}$.

Od członków LKK oczekiwano również udziału w uroczystościach mających charakter patriotyczny, między innymi każdorocznie w maju starano się gremialnie uczestniczyć w obchodach upamiętniających uchwalenie Konstytucji 3 maja ${ }^{98}$. Z kolei w maju 1935 roku kupcy z Kongregacji znaleźli się w grupie inicjatywnej budowy pomnika Józefa Piłsudskiego na stokach lwowskiej cytadeli99 ${ }^{99}$ Ze względów ekonomicznych do realizacji tego planu jednak nie doszło.

Kongregacja nie stroniła również od wspierania akcji noszących znamiona charytatywnych. Jako potwierdzenie tej opinii należałoby wskazać poparcie inicjatywy budowy domu wypoczynkowego we Lwowie, a przeznaczonego dla polskiej młodzieży szkolnej ${ }^{100}$. Głównym animatorem przedsięwzięcia był Komitet Opieki nad Zdrowiem Młodzieży Szkół Średnich mający swoją siedzibę przy ulicy Łyczakowskiej ${ }^{101}$. Kupcy lwowscy związani z Kongregacją uczestniczyli również w 1937 roku w zbiórce funduszy w ramach tak zwanej pomocy zimowej, które następnie przeznaczono na pomoc osobom bezrobotnym ${ }^{102}$. W celu rozpropagowania akcji w wielu sklepach i aptekach Lwowa sprzedawano czerwone naklejki cegiełki z napisem „Pomoc Zimowa". Koszt jednej wynosił 10 groszy. Za zgromadzone środki zakupiono między innymi artykuły spożywcze i węgiel dla najbardziej potrzebujących lwowian ${ }^{103}$.

\section{KONTAKTY ZEWNĘTRZNE}

Lwowska Kongregacja Kupiecka ze względu na swoją wieloaspektową działalność utrzymywała kontakty z licznymi instytucjami i organizacjami z sektora gospodarki oraz samorządu terytorialnego. Jej interesy na zewnątrz formalnie mogli reprezentować: prezes oraz trzech wiceprezesów ${ }^{104}$. Lektura zachowanej dokumentacji pozwala wnioskować, że zażyłe kontakty (poza oczywiście Stowarzyszeniem Wzajemnej Pomocy Kupców i Młodzieży Handlowej) łączyły Kongregację z Izbą Przemysłowo-Handlową we Lwowie. Relacje Kongregacji z Izbą wynikały z ustawowych

96 Ibidem, k. 11.

97 A. Biedrzycka, op. cit., s. 681.

98 CDIAL, f. 702 , op. 1, spr. 16, k. 5.

99 A. Biedrzycka, op. cit., s. 747.

${ }^{100}$ CDIAL, f. 702, op. 1, spr. 8, s. 17-19.

101 Celem Komitetu Opieki nad Zdrowiem Młodzieży Szkół Średnich była pomoc młodzieży polegająca m.in. na organizacji w okresie wakacyjnym tygodniowych kolonii dla 300-350 uczniów i uczennic. CDIAL, f. 702, op. 1, spr. 8, k. 17.

102 A. Biedrzycka, op. cit., s. 850.

103 „Gazeta Lwowska”, 25 III 1937.

104 DALO, f. 1, op. 54, spr. 2176, k. 82. 
kompetencji tej ostatniej ${ }^{105}$. Mając na uwadze powyższe argumenty, Izba między innymi obligowała lwowską Kongregację do przekazywania, w odstępach trzymiesięcznych, sprawozdań z „najważniejszych wydarzeń”, jakie miały miejsce w stosunkach handlowych panujących na obszarze działania LKK ${ }^{106}$. Przykładowo wśród informacji zamieszczonych w sprawozdaniu za pierwszy kwartał 1935 roku władze Kongregacji donosiły o trendach ekonomicznych panujących w branżach: obuwniczej, papierniczo-piśmienniczej, kolonialno-spożywczej, fotograficzno-radiowej, samochodowej, porcelanowo-szklanej, drogeryjno-farbowo-perfumeryjnej, meblarskiej, sukienniczo-bławatnej, sportowej oraz żelaznej ${ }^{107}$. Najprawdopodobniej wiadomości zdobyte $\mathrm{w}$ ten sposób służyły następnie urzędnikom Izby do sporządzania raportów na temat położenia (potrzeb i niedomagań) polskiego handlu. Warto jednak w tym miejscu nadmienić, że zbieranie owych informacji przez organ lwowskich kupców odbywało się drogą korespondencyjną, a mianowicie właściciele firm kupieckich zrzeszonych w Kongregacji przesyłali do jej centrali krótkie raporty zawierające ogólne procentowe dane z obrotów handlowych za okres objęty sprawozdaniem. Niestety nie ma pewności, w jakim stopniu były one przygotowywane rzetelnie i rzeczywiście odzwierciedlały kondycję poszczególnych przedsiębiorstw. Należy zaznaczyć, że raczej miały wydźwięk pesymistyczny, co należy tłumaczyć powszechnym regresem gospodarczym ${ }^{108}$.

Izba Przemysłowo-Handlowa we Lwowie prowadziła także wobec Kongregacji Kupieckiej politykę informacyjną, która miała ułatwić członkom LKK kooperowanie z partnerami zagranicznymi ewentualnie ostrzec lwowskich kupców przed pojawiającymi się zagrożeniami przy nawiązywaniu współpracy. Chociażby w styczniu 1927 roku władze IPH na wniosek polskiego konsulatu działającego w rumuńskim Gałaczu (rum. Galați) nawoływały do zachowania wyjątkowej ostrożności przy podpisywaniu umów handlowych z firmami rumuńskimi. W celu uniknięcia nierzetelnych przedsiębiorstw między innymi za pośrednictwem Izby rozsyłano dane na temat zdolności kredytowych potencjalnych kontrahentów z Rumunii ${ }^{109}$.

Innym razem władze lwowskiej Izby dyscyplinowały kierownictwo Kongregacji w sprawie uchybień prawnych odnotowanych wśród lokalnych kupców. Problematyczna kwestia dotyczyła nagminnego lekceważenia obowiązującego wówczas prawa przemysłowego, a dokładniej zapisu mówiącego o stosowaniu nazewnictwa firmy zawierającej nazwisko jej właściciela. Jako przykłady potwierdzające powyższy zarzut, prezydium Izby w lipcu 1935 roku wskazywało przedsiębiorstwa zarejestrowane bezimiennie, a widniejące w rejestrach pod nazwami: „Flora”, „Nicea” czy „Record Cravates”"10. Obawy Izby nie były, jak się okazuje, bezpodstawne.

${ }^{105}$ Zob. Rozporządzenie Prezydenta Rzeczypospolitej z dnia 15 VII 1927 r. o izbach przemysłowo-handlowych (Dz.U. 1927, nr 67, poz. 591); S. Hoszow ski, Ekonomiczny rozwój Lwowa w latach 1772-1914, Lwów 1935, s. 76-78.

106 CDIAL, f. 702, op. 1, spr. 21, k. 2.

107 Ibidem, k. 3.

${ }^{108}$ Ibidem, k. 5, 8-10, 12-13, 15-16, 19, 21, 23, 32, 53, 59.

109 CDIAL, f. 702, op. 1, spr. 1, k. 10.

${ }^{110}$ CDIAL, f. 702, op. 1, spr. 26, k. 4. 
Często bowiem zdarzały się przypadki, kiedy wierzyciele zlikwidowanej firmy nie mogli dochodzić swoich praw i roszczeń finansowych, gdyż pojawiał się problem z ustaleniem jej właściciela. W tym miejscu należy zaznaczyć, że niezastosowanie się władz Kongregacji do uwag Izby mogło skutkować stosowną interwencją w sądach rejestrowych ${ }^{111}$. Lwowska Izba Przemysłowo-Handlowa wykorzystywała także miejscową Kongregację do kolportowania różnorakich komunikatów czy odezw. Egzemplifikując, w kwietniu 1935 roku za pośrednictwem Kongregacji zachęcano do subskrybowania rządowej trzyprocentowej Premiowej Pożyczki Inwestycyjnej ${ }^{112}$.

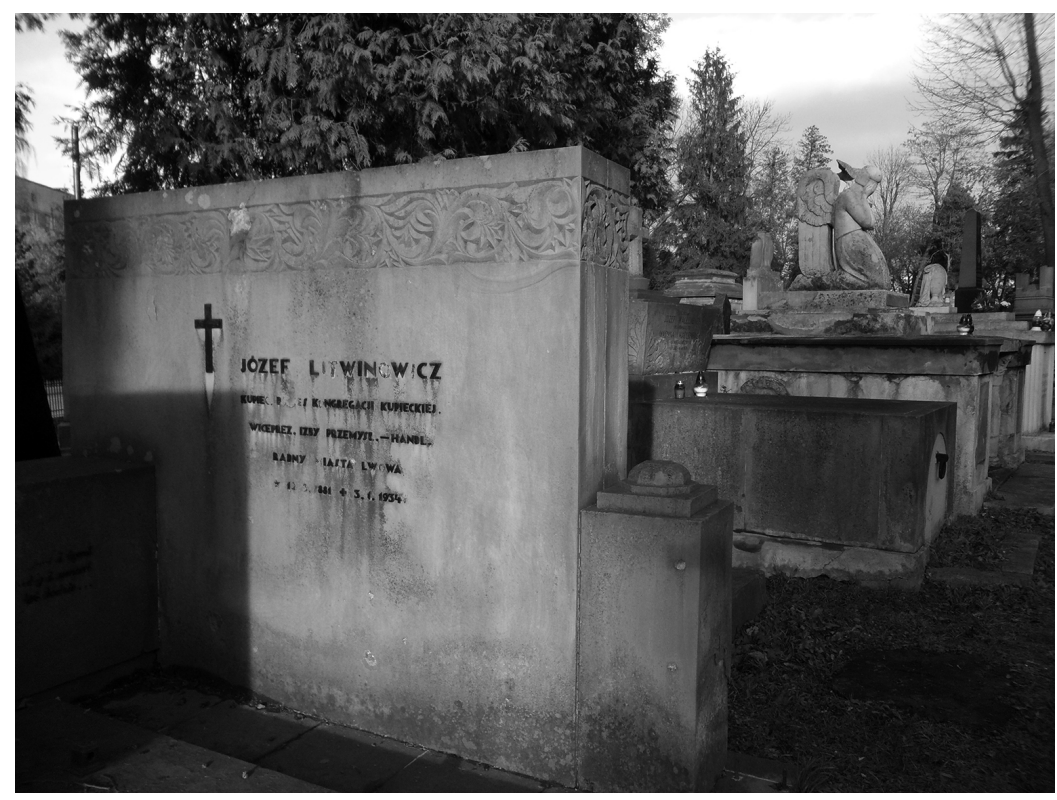

Fot. 1. Grobowiec Józefa Litwinowicza na cmentarzu Łyczakowskim we Lwowie (fot. K.M.) Źródło: ze zbiorów własnych autora.

Trudno nie wspomnieć w tym miejscu, że delegaci LKK, ze względu na pozycję organizacji byli zapraszani do gremiów decyzyjnych we Lwowie. Przykładem potwierdzającym tę opinię może być fakt przynależności jej członków w 1927 roku do Rady Przybocznej powołanej przy Janie Strzeleckim - komisarzu rządowym sprawującym nadzór nad magistratem po śmierci dotychczasowego, wieloletniego, prezydenta Lwowa Józefa Neumanna ${ }^{113}$. Zresztą prezes LKK, a zarazem członek wspomnianej

\footnotetext{
111 Ibidem.

112 Ibidem, k. 1-2.

113 A. Biedrzycka, op. cit., s. 382.
} 
Rady Przybocznej, Józef Litwinowicz, we wrześniu 1927 roku podniósł publicznie fakt małej reprezentacji lwowskiego kupiectwa przy komisarzu rządowym ${ }^{114}$.

Warto nadmienić, że kupcy zrzeszeni w Kongregacji chętnie i niemal zawsze uczestniczyli w wydarzeniach istotnych dla lokalnej społeczności, a w szczególności chrześcijan zamieszkujących Lwów. Na przykład 24 marca 1923 roku liczne grono reprezentantów Kongregacji wzięło udział w uroczystym pogrzebie arcybiskupa Lwowa Józefa Bilczewskiego ${ }^{115}$. Innym razem, w czerwcu 1928 roku, towarzyszyli urzędnikom wojewódzkim i przedstawicielom lwowskich Kościołów (greckiego i rzymskiego) w powitaniu we Lwowie prymasa Polski Augusta Hlonda ${ }^{116}$.

\section{RELACJE Z KUPCAMI ŻYDOWSKIMI}

$\mathrm{Na}$ odrębną uwagę zasługują stosunki łączące członków lwowskiej Kongregacji z kupcami żydowskimi, którzy liczebnie zdominowali lwowski handel ${ }^{117}$. Zasadniczo relacje te były raczej negatywne, co należałoby thumaczyć nie tylko konserwatyzmem członków LKK, ale przede wszystkim rywalizacją gospodarczą, szczególnie intensywną w latach postępującej depresji ekonomicznej. Jednym z najważniejszych postulatów lwowian skupionych wokół Kongregacji pozostawała chęć utrzymania w mocy prawnej zakazu niedzielnego handlu, co oczywiście podważała społeczność żydowska, argumentując przy tym, że chrześcijańscy kupcy są uprzywilejowani, mając czynne sklepy, składy, punkty handlowe w soboty, kiedy w tym samym czasie żydowskie - ze względów religijnych - pozostają zamknięte. Jak się okazuje, dla członków LKK sprawa utrzymania status quo w tej materii pozostawała kluczowa, i to nie tylko we Lwowie, lecz w całym kraju. Kwestię tak zwanego spoczynku niedzielnego dyskutowano na forum ogólnopolskim niemal cały okres międzywojenny. Był to temat sztandarowy podczas organizowanych przez Naczelną Radę Kupiectwa Polskiego (pod auspicjami której - przypomnę - funkcjonowała również lwowska

${ }_{114}$ Ibidem. Józef Litwinowicz urodził się w 1880 r. we Lwowie. W wieku nieco ponad 30 lat uruchomił własną firmę handlową. Jego sklep przy ulicy Halickiej wyspecjalizował się w handlu towarami bławatnymi i płóciennymi. Od 1919 r. był sekretarzem honorowym Kongregacji, a ponadto pozostawał również wiceprezesem Izby Handlowo-Przemysłowej, działaczem Bezpartyjnego Bloku Wspierania Rządu oraz radnym miejskim we Lwowie. Zmarł w I 1934 r. Na znak żałoby w dniu pogrzebu wszystkie sklepy, których właściciele należeli do Kongregacji, zamknięto. Jego grób znajduje się nieopodal głównej bramy wejściowej na cmentarz Łyczakowski. „Kupiec Polski”, R. XVII, 1-15 I 1934; К. Курилишин, Часопис „Галичанинъ” (Львів, 1893-1913 рр.). Матеріали до біобібліографістики, ДрогобичКоло 2013, s. 537.

${ }^{115}$ К. Курилишин, op. cit., s. 192.

116 Ibidem, s. 416.

${ }_{117}$ Według stanu na rok 1938 kupcy żydowscy posiadali we Lwowie 4616 zarejestrowanych przedsiębiorstw trudniących się handlem detalicznym, co stanowiło nieco ponad $71 \%$ wszystkich zlokalizowanych w mieście firm tego typu. Rzymscy katolicy mieli ich „zaledwie” 1470. Pozostałe przedsiębiorstwa należały do osób deklarujących wyznanie greckokakotlickie (340), ewangelickie (29) oraz prawosławne (19). Więcej na ten temat w: A. Bezsmertnyj, Handel lwowski.., s. 15 (tab. 3). 
Kongregacja) zjazdów kupieckich ${ }^{118}$. W latach 30 . XX wieku żądano wprowadzenia w życie rozporządzenia prezydenta Ignacego Mościckiego z 1928 roku regulującego (po myśli członków chrześcijańskich kupców) przepisy odnośnie do godzin handlu ${ }^{119}$. W samym Lwowie protesty w sprawie ograniczenia handlu w niedzielę Kongregacja organizowała we współpracy z Polskim Związkiem Hodowców ${ }^{120}$. W sprawach strategicznych chrześcijanie skupieni wokół Kongregacji nie stronili jednak od współpracy z żydowskimi organizacjami kupieckimi ${ }^{121}$. Na przykład w dniu 6 marca 1929 roku Żydzi oraz chrześcijanie planowali wystąpić razem na „zgromadzeniu publicznym" zorganizowanym w celu wyrażenia dezaprobaty dla projektu ustawy dotyczącej podwyżki czynszów ${ }^{122}$.

Na kanwie osobistej relacji kupiectwa chrześcijańskiego i żydowskiego nierzadko przedstawiały się nader pozytywnie. Oficjele Kongregacji uczestniczyli w ważnych z perspektywy żydowskiej wydarzeniach. Znamienny pozostaje przykład udziału reprezentacji chrześcijańskiego kupiectwa w pogrzebie jednego z najwybitniejszych działaczy żydowskiej społeczności Lwowa początków XX wieku, Maurycego Rappaporta (vel Rapaporta). Wspomniana uroczystość pogrzebowa odbyła się 6 maja 1926 roku i według jej uczestników była „wielką manifestacją żałobną żydowskiej ludności"123. Warto w tym miejscu nadmienić, że zmarły zasłużył się przede wszystkim jako wieloletni prezes Lwowskiego Stowarzyszenia Kupców, organizacji utworzonej w 1904 roku i odgrywającej rolę swoistego katalizatora dla żydowskich kupców ${ }^{124}$. W okresie międzywojennym stowarzyszenie to stanowiło bezapelacyjnie największą konkurencję na terenie Lwowa dla działań podejmowanych przez członków chrześcijańskiej Kongregacji. Ponadto chrześcijańscy kupcy skupieni wokół LKK występowali wspólnie z przedstawicielami handlu żydowskiego przeciwko nadużyciom w handlu ${ }^{125}$. Próbowano wyeliminować sprzedawców ulicznych i akwizytorów, którzy - w zamyśle kupców stacjonarnych - nie opłacali podatków, ubezpieczenia oraz innych kosztów pośrednich ${ }^{126}$. Walka ta przyniosła z czasem

118 CDIAL, Kongregacja Kupiecka we Lwowie, sygn. f. 702, op. 1, spr. 17, k. 27, 30.

119 Zob. Rozporządzenie Prezydenta Rzeczypospolitej z dnia 22 III 1928 r. (Dz.U. z 1928 r., nr 38, poz. 364); por. też Ustawa z dnia 18 XII 1919 r. o czasie pracy w przemyśle i handlu, art. $10 \mathrm{i}$ art. 11 (Dz.U. 1920, nr 2, poz. 7).

${ }^{120}$ A. Biedrzycka, op. cit., s. 356.

${ }^{121}$ We Lwowie okresu międzywojennego spośród najaktywniejszych żydowskich organizacji kupieckich należy wymienić Lwowskie Stowarzyszenie Kupców, Stowarzyszenie Rękodzielników Jad Charuzim, Centralny Związek Kupców i Przemysłowców, Organizacja Kupców i Przemysłowców, Stowarzyszenie Drobnych Kupców i Handlarzy i Stowarzyszenie Detalistów Spożywczych. CDIAL, f. 702, op. 1, spr. 8, k. 57; A. Bezsmertnyj, Lwowskie organizacje kupieckie..., s. 369, 374.

122 CDIAL, f. 702, op. 1, spr. 8, k. 57.

${ }^{123}$ Lwowska Narodowa Naukowa Biblioteka Ukrainy im. Wasyla Stefanyka/Львівська національна наукова бібліотека України імені В.Стефаника, sygn. f. 176: Zbiór Wybranowskich, nr 15: Izba Przemysłowo-Handlowa, k. 10.

124 Ibidem, k. 9.

${ }^{125}$ A. Bezsmertnyj, Handel lwowski..., s. 15.

${ }^{126}$ CDIAL, Kongregacja Kupiecka we Lwowie, sygn. f. 702, op. 1, spr. 17, k. 28; T. Kargol, Izba Przemystowo-Handlowa w Krakowie w latach 1850-1939, Kraków 2003, s. 136; A. Biedrzycka, op. cit., s. 984. 
oczekiwane rezultaty. Władze miejskie wydały nawet stosowne decyzje ograniczające handel uliczny przy wybranych ulicach i placach Lwowa. W lutym 1936 roku zakazem objęto ulice: Boimów, Halicką, Serbską, a także Rynek ${ }^{127}$.

\section{PODSUMOWANIE}

W okresie międzywojennym Lwowska Kongregacja Kupiecka bez wątpienia pozostawała jednym z głównych organizatorów życia gospodarczego w Małopolsce Wschodniej. O randze tej organizacji świadczy systematycznie rosnąca liczba jej członków, którzy de facto mogli liczyć na wsparcie ze strony Kongregacji, szczególnie w trudnych latach depresji ekonomicznej. Lwowska Kongregacja Kupiecka pomimo krótkiego żywota, w porównaniu ze swoją długowieczną krakowską odpowiedniczką, odnotowała kilka znaczących sukcesów. Do najważniejszych należy zaliczyć uruchomienie we Lwowie Dokształcającej Szkoły Handlowej, która na stałe wpisała się w pejzaż miasta nad Pełtwią. Spore zasługi poniesiono również na polu promocji produktów pozostających w ofercie kupców zrzeszonych pod szyldem Kongregacji. Nie bez znaczenia była również ścisła współpraca pomiędzy władzami LKK i Izby Handlowo-Przemysłowej (często w obu instytucjach zasiadały te same osoby), które wspólnymi siłami podejmowały działania mające na celu poprawę stanu kupiectwa we Lwowie okresu międzywojennego.

127 A. Bezsmertnyj, Handel lwowski..., s. 15. 


\section{ANEKS 1}

Wykaz członków Lwowskiej Kongregacji Kupieckiej w latach 1923-1924

\begin{tabular}{|c|c|}
\hline Imię i nazwisko (ew. nazwa firmy) & Adres firmy \\
\hline Abrysowski Julian i Stachiewicz & Rynek 32 \\
\hline Abl Stanisław & Sykstuska 3 \\
\hline Adamski Władysław & Akademicka 5 \\
\hline Aczkiewicz Władysław & Gródecka 55 \\
\hline Błocki Bolesław & Akademicka 8 \\
\hline Bartosz Artur & Kopernika 2 \\
\hline Bromilski Jan & Legionów \\
\hline Bujak Jan & Kopernika 4 \\
\hline Barabasz Wacław & Pańska 11 \\
\hline Baczewski Leopold & Rynek 32 \\
\hline „Budulec” & Kopernika 5 \\
\hline Burjanowa Maria & Leona Sapiehy 19 \\
\hline Bohosiewicz Bogdan & Hetmańska 6 \\
\hline Buczkowski Stanisław & Pańska 23 \\
\hline Buszek Władysław & Akademicka 6 \\
\hline Baran Stanisław & Akademicka 26 \\
\hline Bojarski Eugeniusz & Czarnieckiego 2 \\
\hline Czołowski Stanisław & plac Mariacki \\
\hline Chladek Franciszek & Rynek 45 \\
\hline Czaykowski Zygmunt & Rynek 27 \\
\hline Czerwieński Władysław (Wójcikwieczowa) & Halicka 24 \\
\hline Csernak Mieczysław & Halicka 20 \\
\hline Ciechulski Władysław & Legionów 2 \\
\hline Cwanarski Stanisław & - \\
\hline Drexler Kazimierz & plac Kapitulny 2 \\
\hline Dąbrowski Julian & Akademicka 2 \\
\hline Ditmar R. Brünner & plac Mariacki 9 \\
\hline Dąbrowska Józefa & Akademicka 3 \\
\hline Dąbrowski Bronisław & Akademicka 3 \\
\hline Dom Handlowy Komis. „Wschód” & Sykstuska 19 \\
\hline Eckert Antoni & Kochanowskiego 22 \\
\hline Friczyk Julian & Kilińskiego 2 \\
\hline
\end{tabular}




\begin{tabular}{|c|c|}
\hline Gustowicz Tadeusz & Zimorowicza 16 \\
\hline Güttler Ferdynand & Halicka 20 \\
\hline Głogowska Helena & Piekarska 1 \\
\hline Grollo Adolf & Pańska 11 \\
\hline Górski Bronisław & plac Mariacki 9 \\
\hline Górniak \& Chruszczewski & Akademicka 3 \\
\hline Górski \& Witek & plac Mariacki 5 \\
\hline Grocholski Zenon & Wałowa 191 \\
\hline Hoszowski Ludwik & Akademicka 1 \\
\hline Hawranek Edward & plac Mariacki 9 \\
\hline Halski Józef & Sobieskiego 5 \\
\hline Hübner Alojzy & Rynek 38 \\
\hline Hoffman Jan & Trybunalska 6 \\
\hline $\begin{array}{l}\text { „Hartwig” Towarzystwo Akcyjne Dom } \\
\text { Spedycyjno-Handlowy }\end{array}$ & Sykstuska 19 \\
\hline Hegedüss Ludwik & Kętrzyńskiego 11 \\
\hline Jarzyna Jan & plac Mariacki 4 \\
\hline Jaroszewski Bolesław & Romanowicza 9 \\
\hline Justian Józef & Teatyńska 7 \\
\hline Kauczyński Adam „Hurtownia kolonialna” & Klementyny Tańskiej 3 \\
\hline Krupiński Karol & Akademicka 12 \\
\hline Królikiewicz Jan & Akademicka 24 \\
\hline Klimkiewicz Jan & Akademicka 24 \\
\hline Kistryn Stanisław & plac Halicki 21 \\
\hline Kierski Grzegorz Jerzy & Pasaż Mikolascha \\
\hline Krawjański Franciszek & Sykstuska 9 / plac Mariacki \\
\hline Kisslinger Bogumił & 3 Maja 2 \\
\hline Krzysiak Roman & Podlewskiego 7 \\
\hline Kierski Alfons Marian & Szajnochy 2 \\
\hline Kulinowski Stefan & Gródecka 13 \\
\hline Kościuk Marian & Czarnieckiego 1 \\
\hline Krajewski Zygmunt & Batorego 4 „Pilot”?? \\
\hline Kubala Kazimierz & Batorego 4 „Pilot” \\
\hline Kafka Marian & Krakowska \\
\hline Imię i nazwisko (ew. nazwa firmy) & Adres firmy \\
\hline Kadernożka Jan & - \\
\hline Klimowicz Stanisław & Kopernika 14 \\
\hline
\end{tabular}




\begin{tabular}{|c|c|}
\hline „Kalka” Fabryka papierów chemicznych & - \\
\hline Knauer i Syn & plac Kapitulny 2 \\
\hline Krajowy Związek Handlowców & Lindego 6 \\
\hline Koleżeński Józef & Batorego $34 \mathrm{a}$ \\
\hline Lewicki Aleksander & plac Mariacki 10 \\
\hline Ligęza Władysław & plac Halicki 2 \\
\hline Litwinowicz Józef & Halicka 21 \\
\hline Ludwig Jan & Krakowska 38 \\
\hline Lewicki Michał & Zyblikiewicza 2 \\
\hline Łopuszański \& Sauczey & plac Mariacki \\
\hline Lisowski Stanisław - Leśkowicz & Rutowskiego 7 \\
\hline Lödl Adolf & Potockiego 32 \\
\hline Motylewski Stanisław \& Krzyszkowski & plac Mariacki \\
\hline Mieszkowski Kazimierz & plac Mariacki 4 \\
\hline Mihułowicz Dionizy & Kętrzyńskiego 25 \\
\hline Mikolasch i Spółka & Kopernika 1 \\
\hline Maksymowicz Kazimierz & Sokoła 4 \\
\hline Makarowski Karol & Batorego 14 \\
\hline Marcin Müller & plac Halicki 14 \\
\hline Malimon Aleksander & Wałowa 11 \\
\hline Majwald Stanisław & Sobieskiego 9 \\
\hline Mikuszewski Jan & Kilińskiego 1 \\
\hline Mensik Alfons & Wałowa 11 \\
\hline Muszyński Jan & Grodzickich 3 \\
\hline Nowak Józef & plac Halicki \\
\hline Niemojewski Stefan & Asnyka 9 \\
\hline Niewczyk Franciszek & Gródecka \\
\hline Niżnikiewicz August & Hetmańska 4 \\
\hline Oberski Leon & Legionów 5 \\
\hline Oźmiński Józef & Halicka 5 \\
\hline Quest Jan & Rynek 37 \\
\hline Opolska Maria & Zyblikiewicza 3 \\
\hline Pawłowski Jan & plac Mariacki 7 \\
\hline Pawłowski Antoni & Akademicka 4 \\
\hline Piller Piotr & Trybunalska 14 \\
\hline Pfützner Adolf & Słowackiego \\
\hline Pawlikowski Karol & Nowej Rzeźni 1 \\
\hline
\end{tabular}




\begin{tabular}{|c|c|}
\hline Pirkel Bogumił & Akademicka 3 \\
\hline Połoniecki Bernard & Akademicka 2 \\
\hline Pilaciński Piotr & Lwowskich Dzieci 10 \\
\hline Paczosiński Adam & Leona Sapiehy 2 \\
\hline „Pezet” Zakłady budowalne & Akademicka \\
\hline Przedsiębiorstwo Handlowe „Małopolanin” & Sobieszczyzna 9 \\
\hline Riedl Jan & Akademicka 2 \\
\hline Riedl Kazimierz & Rutowskiego 3 \\
\hline Riedl Edmund & Rutowskiego 3 \\
\hline Rehman Stanisław & Rutowskiego 2 \\
\hline Rucker Jan & Listopada 20 \\
\hline Rubel Włodzimierz & Szajnochy 2 \\
\hline [nazwisko nieczytelne - K.M.] Władysław & Batorego 4 „PILOT” \\
\hline [nazwisko nieczytelne - K.M.] Stanisław & plac Smolki 4 \\
\hline [nazwa firmy nieczytelna - K.M.] & plac Trybunalski \\
\hline [nazwisko nieczytelne - K.M.] Władysław & Potockiego 39 \\
\hline [nazwisko i imię nieczytelne - K.M.] & Akademicka 3 \\
\hline Scheyer Julian & Akademicka 5 \\
\hline Socki Stanisław & Akademicka 3 \\
\hline Solecki Leonard & Batorego 2 \\
\hline Starzewski Mieczysław & Halicka 24 \\
\hline Schuster Józef & Rutowskiego 10 \\
\hline Starck Fryderyk & Legionów 1 \\
\hline Szkwiron Albert & Kopernika 3 \\
\hline Siwek Wincenty & Kopernika 5 \\
\hline Scherz [?] Ottokar & Sykstuska 3 \\
\hline Szulc Stanisław & Akademicka 8, ,Sarmacja”’?> \\
\hline Skrzypek Leon & Pasaż Mikolascha 1 \\
\hline Smalski Stanisław & Halicka 5 \\
\hline Skibiński Kazimierz & Kopernika 4 \\
\hline Schuman Ryszard & Pańska 21 \\
\hline Stępkowicz Stanisław & plac Kapitulny $1 / 1$ \\
\hline Imię i nazwisko (ew. nazwa firmy) & Adres firmy \\
\hline Skorodecki Ferdynand & Kilińskiego 24 \\
\hline Skulski Władysław Dyr. Tow. „Ryngraf” & - \\
\hline Stowarzyszenie Kupców Polskich & plac Smolki 4 \\
\hline Tkacz Stanisław & Hetmańska 10 \\
\hline
\end{tabular}




\begin{tabular}{|l|l|}
\hline Uwiera Alfons & Plac Halicki 14 \\
\hline Uwiera Antoni & Halicka 10 \\
\hline Vogl Stanisław & Jagiellońska \\
\hline Woźniak Stanisław & Akademicka 8 \\
\hline Wroński Eugeniusz & plac Halicki 2 \\
\hline Wierzbicki Stanisław & Halicka 24 \\
\hline Winkler Maksymilian & Rynek 28 \\
\hline Weyde Rudolf & Batorego 4 \\
\hline Weyde Kazimierz & Batorego 4 „Pilot” \\
\hline Weyde Jan & Batorego 4 „Pilot” \\
\hline Weyde Adam & Batorego 4 „Pilot” \\
\hline Wagner Stanisław & plac Mariacki 7 \\
\hline Wątorski Leon & plac Kapitulny \\
\hline Wroński Franciszek & plac Mariacki 10 \\
\hline Wietchy Adolf & Dekerta 4 \\
\hline Zalewski Ludwik & Akademicka 22 \\
\hline Zwoliński Florian & Hetmańska 10 \\
\hline Zacharjasiewicz [brak imienia - K.M.] & Głęboka 19 \\
\hline Zawadzki Ludwik & Sobieskiego 5 \\
\hline Związek Handlowy & Lindego 6 \\
\hline Zakopane Meor Stacheiwicz [pisownia & Akademicka 27 \\
\hline oryg. - K.M.] & Batorego 26 \\
\hline Zieliński Andrzej Stanisław & Łyczakowska 17 \\
\hline Żywczak Gabriel & Kilińskiego \\
\hline Żylski Klaudiusz & Akademicka 14 \\
\hline & \\
\hline
\end{tabular}

Źródło: DALO, f. 2, op. 26, spr. 254, k. 7-11. 


\section{ANEKS 2}

Wykaz członków Zarządu i Wydziału Kongregacji Kupieckiej (wg stanu na 1934 r.)

\begin{tabular}{|c|c|c|}
\hline Imię i Nazwisko & Adres & Uwagi \\
\hline \multicolumn{3}{|c|}{ Zarząd } \\
\hline Pfau Jan Kanty & Rynek 30 & Prezes \\
\hline Schayer Julian & ul. Krzywa 10 & I Wiceprezes \\
\hline Maksymowicz Kazimierz & ul. Sokoła 1 & II Wiceprezes \\
\hline Kistryn Stanisław & ul. Halicka 21 & III Wiceprezes \\
\hline Grocholski Zenon & ul. Wałowa 9 & Skarbnik \\
\hline Witek Tadeusz & ul. Halicka 4 & Sekretarz \\
\hline Górski Tadeusz & pl. Mariacki 5 & Zastępca Sekretarza \\
\hline \multicolumn{3}{|l|}{ Wydzial } \\
\hline Bohosiewicz Bogdan & ul. Hetmańska 6 & \multirow[t]{17}{*}{ Członkowie Wydziału } \\
\hline Borowski Stanisław & pl. Mariacki 1 & \\
\hline Czołowski Stanisław & pl. Mariacki 8 & \\
\hline Cwetler Tadeusz & pl. Mariacki 8 & \\
\hline Gorgolewski Roman & ul. Działyńskich 9 & \\
\hline Górniak Michał & ul. Akademicka 3 & \\
\hline Hoszowski Ludwik & ul. Akademicka 3 & \\
\hline Krupiński Karol & ul. Ponińskiego 31 & \\
\hline Lewicki Aleksander & pl. Mariacki 10 & \\
\hline Moor Antoni & ul. Akademicka 24 & \\
\hline Pawłowski Jan & pl. Mariacki 5 & \\
\hline Quest Jan & Rynek 37 & \\
\hline Riedl Edmund & ul. Rutowskiego 3 & \\
\hline Stefanowicz Józef & ul. Głowińskiego 29 & \\
\hline Sudhoff Jan & ul. Akademicka 8 & \\
\hline Victorin Henryk & ul. Hetmańska 6 & \\
\hline Welz Hieronim & ul. Akademicka 5 & \\
\hline
\end{tabular}

Źródło: DALO, f. 1, op. 54, spr. 2176, k. 85. 


\section{BIBLIOGRAFIA}

\section{Archiwa i biblioteki}

Austriacka Biblioteka Narodowa w Wiedniu / Österreichische Nationalbibliothek:

Statut Stowarzyszenia Młodzieży Handlowej we Lwowie, Lwów 1868 (sygn. 123111-B).

Centralne Państwowe Archiwum Historyczne Ukrainy we Lwowie / Центральний Державний Історичний Архів України у Львові:

Fond 702 , opis 1 , sprawa 8.

Fond 702, opis 1, sprawa 15.

Fond 702, opis 1, sprawa 16.

Fond 702, opis 1, sprawa 17.

Fond 702, opis 1, sprawa 19.

Fond 702, opis 1, sprawa 21.

Fond 702, opis 1, sprawa 24.

Fond 702, opis 1, sprawa 25.

Fond 702, opis 1, sprawa 26.

Fond 702, opis 1, sprawa 29.

Fond 702, opis 1, sprawa 30.

Fond 702, opis 1, sprawa 31.

Fond 702, opis 1, sprawa 33.

Fond 702, opis 1, sprawa 34.

Fond 702, opis 1, sprawa 36.

Lwowska Narodowa Naukowa Biblioteka Ukrainy im. Wasyla Stefanyka / Львівська національна наукова бібліотека України імені В.Стефаника:

Fond 176: Zbiór Wybranowskich, nr 15, Izba Przemysłowo-Handlowa.

Państwowe Archiwum Obwodu Lwowskiego / Державний Архів Львівської Області /Derżawnyj Archiw Lwiwśkoji Obłasti:

Fond 1, opis 54, sprawa 350.

Fond 1, opis 54, sprawa 2115.

Fond 1, opis 54, sprawa 2176.

Fond 1, opis 54, sprawa 2178.

Fond 2, opis 26, sprawa 254.

\section{Źródła drukowane i akty normatywne}

Dziennik Ustaw 1920, nr 2, poz. 7.

Dziennik Ustaw 1927, nr 53, poz. 468.

Dziennik Ustaw 1927, nr 67, poz. 591.

Dziennik Ustaw 1928, nr 38, poz. 364.

Dziennik Ustaw 1934, nr 40, poz. 350.

Skorowidz Przemystowo-Handlowy Królestwa Galicyi, wyd. 2, Lwów 1912.

Statut Kongregacyi Kupieckiej we Lwowie [b.d.m.w.] 


\section{Akty prawne}

Rozporządzenie Prezydenta Rzeczypospolitej z dnia 22 marca 1928 r. (Dz.U. 1928, nr 38, poz. 364).

Ustawa z dnia 18 grudnia 1919 r. o czasie pracy w przemyśle i handlu, art. $10 \mathrm{i}$ art. 11 (Dz.U. 1920, nr 2, poz. 7).

\section{Prasa}

„Gazeta Lwowska”, 25 III 1937.

„Kupiec Polski”, 1-15 I 1934.

„Kupiec Polski. Organ kupiectwa polskiego”, R. IV, nr 14, 15 VII 1910.

\section{Opracowania}

Bezsmertnyj A., Handel lwowski w okresie międzywojennym, „Dzieje Najnowsze”, R. XLVII, 2015, z. 2, Warszawa.

Bezsmertnyj A., Lwowskie organizacje kupieckie w okresie międzywojennym, „Roczniki

Dziejów Społecznych i Gospodarczych” 2017, t. LXXVIII, s. 367-385.

Biedrzycka A., Kalendarium Lwowa 1918-1939, Kraków 2012.

Hoszowski S., Ekonomiczny rozwój Lwowa w latach 1772-1914, Lwów 1935.

Kargol T., Izba Przemysłowo-Handlowa w Krakowie w latach 1850-1939, Kraków 2003.

Курилишин К., Часопис «Галичанинъ» (Львів, 1893-1913 рр.). Матеріали до біобібліографістики, Дрогобич-Коло 2013.

Мас ик Р., Промислово-торгова палата у Львові у міжвоєнний період, „Наукові зошити історичного факультету Львівського університету” 2015, Випуск 16, s. 205-220.

Włodek R., „Patrz Kościuszko, na nas z”... ekranu. Obraz Naczelnika w filmie [w:] Spoteczeństwo - Kultura - Inteligencja. Studia Historyczne ofiarowane Profesor Irenie Homoli-Skapskiej, red. E. Orman, G. Ni eć, Kraków-Warszawa 2009.

Wygonik-Barzyk E., Krakowska Kongregacja Kupiecka. 600 lat istnienia, Kraków 2009. 
